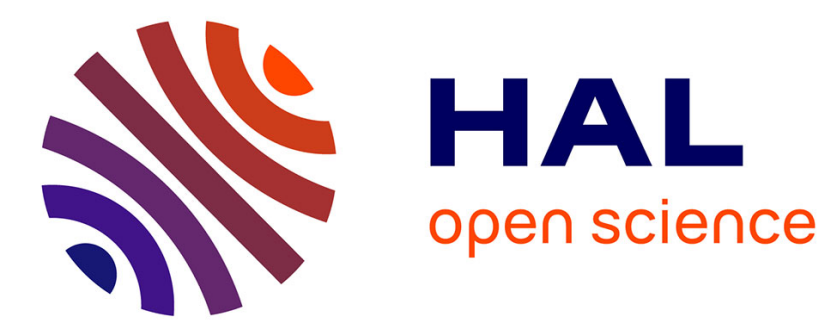

\title{
Linking bacterial type I toxins with their actions
}

Régine Brielle, Marie-Laure Pinel-Marie, Brice Felden

\section{To cite this version:}

Régine Brielle, Marie-Laure Pinel-Marie, Brice Felden. Linking bacterial type I toxins with their actions. Current Opinion in Microbiology, 2016, 30, pp.114-121. 10.1016/j.mib.2016.01.009 . inserm$01274292 \mathrm{v} 2$

\section{HAL Id: inserm-01274292 https://www.hal.inserm.fr/inserm-01274292v2}

Submitted on 20 May 2016

HAL is a multi-disciplinary open access archive for the deposit and dissemination of scientific research documents, whether they are published or not. The documents may come from teaching and research institutions in France or abroad, or from public or private research centers.
L'archive ouverte pluridisciplinaire HAL, est destinée au dépôt et à la diffusion de documents scientifiques de niveau recherche, publiés ou non, émanant des établissements d'enseignement et de recherche français ou étrangers, des laboratoires publics ou privés. 


\section{Linking bacterial type I toxins with their actions}

Régine Brielle, Marie-Laure Pinel-Marie ${ }^{\circ}$ and Brice Felden ${ }^{\circ}$

Inserm U835-Upres EA2311, Pharmaceutical Biochemistry Lab, University of Rennes 1, 2 av. du Prof. Léon Bernard, 35000 Rennes, France.

• Co-corresponding author E-mails: marie-laure.pinel@univ-rennes1.fr and bfelden@univrennes1.fr. 


\begin{abstract}
Bacterial type I toxin-antitoxin systems consist of stable toxin-encoding mRNAs whose expression is counteracted by unstable RNA antitoxins. Accumulating evidence suggests that these players belong to broad regulatory networks influencing overall bacterial physiology. The majority of known transmembrane type I toxic peptides have conserved structural characteristics. However, recent studies demonstrated that their mechanisms of toxicity are diverse and complex. To better assess the current state of the art, type I toxins can be grouped into two classes according to their location and mechanisms of action: membrane-associated toxins acting by pore formation and/or by nucleoid condensation; and cytosolic toxins inducing nucleic acid cleavage. This classification will evolve as a result of future investigations.
\end{abstract}

\title{
Keywords:
}

Toxin-antitoxin systems; RNAs; Type I toxins; Mechanisms of actions; Pore formation; Nucleoid condensation; Nucleases; Cell death; Persistence; Stress response. 
2 Toxin-antitoxin (TA) systems are widespread in bacterial and archaeal genomes. In these

systems, the expression of a stable toxin-encoding messenger RNA (mRNA) leads to stasis or cell

4 death unless an unstable antitoxin counteracts its effects. TA systems were first identified on

5 plasmids, where they ensure plasmid maintenance through post-segregational killing (PSK)

6 mechanisms [1]. TA systems were later identified on chromosomes, sometimes in multiple copies,

7 and on phage-like elements. Although in many cases their functions are unknown, they are

8 involved in programmed cell death, bacterial growth control, defense against the intrusion of

9 foreign genetic material, and persistence [2]. TAs are classified into five types according to the

10 antitoxin's nature and mechanisms of action. Here, we focus exclusively on type I TA systems,

11 characterized by RNA antitoxins that inhibit toxic peptide synthesis [1]. For the four other types,

12 please refer to the review by Goeders and Van Melderen [3].

14 Type I TA loci can be transmitted by vertical gene transfer or in specific lineages by gene

duplications [4]. RNA antitoxins can act in cis or in trans. The majority of the type I antitoxins identified so far are cis-acting antitoxins (e.g., Sib and SprF1 antitoxins [5,6•]), meaning that they overlap and perfectly match the toxin-encoding mRNA. The trans-acting antitoxins (e.g., IstR1 and

OhsC [5]) are located away from the toxin locus and share often limited sequence

complementarities. An exception to this in which a RNA antitoxin controls toxin translation via its non-overlapping sequence was recently described in Staphylococcus aureus [7]. TA RNA duplex formation can either result in toxin mRNA degradation (e.g., RatA [8]) or, more commonly, result in toxin translation inhibition (e.g., IstR1 [9]), or in the combination of the two regulatory mechanisms (e.g., SR4 [10] and SprF1 [6•]) [11].

Most type I toxins identified to date have conserved structural features: they generally contain less than 60 amino acids are hydrophobic and have a putative $\alpha$-helical transmembrane domain, except for SymE and RalR [12,13•]. Despite these similarities, the biological functions and mechanisms of action of type I toxins can be very diverse. Therefore, inspired by Jahn and 
collaborators [14••], type I TA systems were cataloged in this review based on the toxins' currently-known mechanisms of action, and are summarized here in Table 1. Many studies reporting type I toxin functions were based upon episomal overproduction, and deletion of the modules was not often associated with a phenotype. For this reason, it remains difficult to distinguish between the primary and secondary molecular targets of type I toxins.

\section{$1 /$ Membrane-associated type I toxins}

Some membrane-associated type I toxins have been reported to disrupt membrane integrity through pore formation or via nucleoid condensation. However, for many type I toxins, either no, or only one of these mechanisms has been investigated experimentally.

\section{a- Peptides inducing membrane permeation through pore-formation}

Some type I toxins, similar to the phage holin proteins, are membrane-associated peptides that form pores, resulting in a drop in potential and ATP synthesis. Thus, their overexpression leads to cell death, evidenced by the appearance of "ghost" cells with translucent centers and cell material located at the poles. However, in physiological conditions, these pore-forming peptides are involved in diverse biological functions (see the summary in Figure 1).

The Hok toxic peptide in Escherichia coli, expressed from the hok/sok (or parB) locus of the R1 plasmid [1], is an example of pore-forming peptide. It was the first type I TA system discovered on plasmids that confers their maintenance by PSK [15]. hok/sok homologs were identified in the chromosomes of Gram-negative bacteria, suggesting their involvement in other functions $[37,38]$. In response to nutrient starvation, the stringent response alarmone (p)ppGpp interacts with Obg GTPase, resulting in the induction of the hokB toxin-encoding mRNA through an unknown mechanism [16••]. This moderateoverexpression leads to membrane depolarization responsible for a switch to a persistent state. Persister cells are a bacterial subpopulation that enters into a dormant state and thus becomes tolerant to antibiotics. While the deletion of hokB locus has no effect on persistence, possibly due to system redundancies, the overexpression of hokB mRNA is 
essential for Obg-mediated persistence. Another recent study [17•] has demonstrated the involvement of the hok/sok locus in bacterial lag phase expansion. This allows cells to adapt to unfavorable conditions such as elevated temperatures or the presence of antibiotics. In low cell density cultures, the system favors bacterial survival regardless of growth-limiting conditions and could complement existing or defective SOS response mechanism, an inducible DNA repair system [17•]. However, in E. coli, some of the hok/sok copies can be inactivated by insertion sequences [38].

TisB translated from the "tisB-istR1" locus is another pore-forming peptide. The TisB toxic peptide is small, hydrophobic, and spontaneously binds membranes [39]. Chemically-synthesized TisB peptides are assembled as stable transmembrane dimers. The charges on the amphiphilic TisB helix suggest that antiparallel dimers could be assembled by salt bridges, and these narrow channels could enable protons to pass across the hydrophobic membranes. Another study [20] revealed that the positively-charged TisB pores induce selective membrane permeation for hydroxyl anions. In turn, protons and anions passages dissipate the proton motive force (PMF). The TisB pore is so narrow that it is impermeable to intracellular water-soluble components, allowing cell survival. As a consequence, tisB mRNA overexpression causes a drop in ATP levels and an increase of cell death even though in physiological conditions it induces a drop in the PMF and the formation of persister cells [20]. By triggering a dormant state, TisB leads to the shutdown of the major antibiotic targets and induces multidrug tolerance (e.g., in $\beta$-lactams targeting peptidoglycan synthesis, in aminoglycosides inhibiting translation, and in ciprofloxacin reducing DNA replication by inhibiting topoisomerase activity). This phenotype has only been observed in exponentially-growing E. coli cells, corresponding to a higher expression of the genes involved in the SOS response [19]. Persister formation by the SOS-induced TisB toxin involves two strategies for survival: DNA repair activation; and entrance into a dormant state [19].

\section{b- Peptides inducing nucleoid condensation}


The par locus, or the RNAI-RNAIl TA system (see Figure 2), is expressed from the pAD1 plasmid of Enterococcus faecalis and encodes the Fst toxin. The par homologs have been detected in low GC Gram-positive bacteria [22]. The Fst toxic peptide possesses a hydrophobic transmembrane domain that is essential for toxicity and conserved within the Fst/Ldr superfamily. This is followed by an unstructured C-terminal tail, probably located in the cytoplasm [22]. Studies focusing on fst mRNA overexpression have shown short- and long-term effects of the toxin. Firstly, fst mRNA overexpression causes an abnormal nucleoid condensation in E. faecalis, S. aureus, Bacillus subtilis, and E. coli. Alteration of peptidoglycan synthesis, cell division and septum placements were also described in E. faecalis and B. subtilis, resulting in unequal DNA distribution among daughter cells $[23,40]$. While the early effects of $f s t$ toxin-encoding mRNA overexpression are at the chromosomal level, its major impact is the membrane stress that induces the transcription of numerous target genes [23]. The majority of these targeted transcripts encode membraneassociated proteins. These proteins include $A B C$ transporters such as glucan, manganese, and glycine-betaine family transporters which are associated with resistance to numerous antibiotics [41]. Transporter overexpression is harmful to the bacteria, probably through depletion of the cellular ATP pool and/or perturbed membrane integrity, as the Fst-induced responses are diverse and nonspecific. This late expression of the transporters may be a response to the Fst-induced chromosomal structure impairment. fst toxin-encoding mRNA overexpression also induces cell membrane permeation, without "ghost" cell formation, and the arrest of macromolecular synthesis [42]. RNAI-RNAll is the only type I PSK system described so far in Gram-positive bacteria [23], although numerous par homologs have been detected in many bacterial chromosomes [22].

Interestingly, overexpression of the fst-Sm/srSm TA system in Streptococcus mutans causes a significant decrease in the number of persister cells [34]. Moreover, in the opportunistic pathogen E. faecalis, a link was recently identified between the expression of a par homolog and virulence [43••]. The mutant lacking the par homolog is more virulent in insect and mouse models, more efficiently colonizes mouse organs, and survives better inside macrophages and upon oxidative 
stress. The authors suggest that these effects could be involved in the transition from commensalism to virulence $[34,43 \bullet \bullet]$.

In E. coli, overproduction of the LdrD protein, which belongs to the Fst/Ldr superfamily [4], leads to nucleoid condensation [25], suggesting a conserved mechanism of action. Additionally, microarray analysis suggests that overexpression of $I d r D$ mRNA upregulates genes involved in the purine metabolism pathway, and reduces cAMP levels [25]. Interestingly, overexpression of the IdrD mRNA homolog IdrA inhibits ATP synthesis and consequently DNA replication, transcription, and translation, eventually inducing cell growth arrest [44].

The E. coli DinQ toxic peptide is a small transmembrane peptide located in the inner membrane. Its expression is controlled by AgrB antisense RNA and the repressor LexA which downregulates numerous genes involved in the SOS response [45]. Ectopic overexpression of $\operatorname{din} Q \mathrm{mRNA}$ induces membrane depolarization [21]. In an agrB mutant strain, two-fold constitutive overexpression of $\operatorname{din} Q \mathrm{mRNA}$ leads to an increase in UV sensitivity associated with a decrease in intracellular ATP and a delay in nucleoid decompaction and extension after UV irradiation. Moreover, elevated levels of $\operatorname{din} Q \mathrm{mRNA}$ in this mutant have a role in the repair of UV-induced DNA damage through inhibition of conjugal recombination [21]. Thus, the DinQ toxin uses several mechanisms to modulate the E. coli UV response.

Temperature-sensitive bsrG/SR4 system located within the SP $\beta$ prophage in $B$. subtilis is probably involved in prophage maintenance within the bacterial chromosome. Indeed, overexpressed bsrG mRNA leads to the accumulation of toxic peptides that inhibit cell growth by targeting the cytoplasmic membrane [26]. Nevertheless, bsrG mRNA overexpression interferes neither with

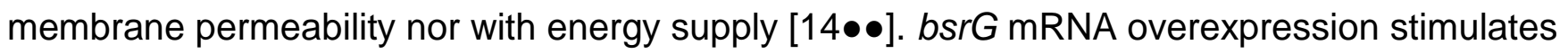
fatty acid biosynthesis, which induces invaginations of the cytoplasmic membrane, leading to abnormal membrane topology, distorted cell division planes, and a reduced cell size. This also results in a delocalization of the cell wall synthesis machinery, including the cytoskeletal component MreB normally associated to the membrane and oriented perpendicularly to the longer cell axis. With the assistance of autolytic enzymes, this disturbance of cell wall synthesis 
machinery leads to cell lysis. Moreover, BsrG toxin induces nucleoid condensation but chromosome segregation and replication are not affected. The nucleoid condensation, in turn,

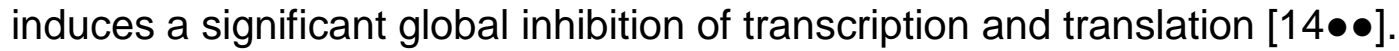

\section{c- Membrane-associated peptides with a mechanism to determined}

There are many other membrane-associated type I toxins with the mechanism of action still to be determined (see Table 1). For many systems, the mechanism was not addressed. For the others, information to classify toxins according to their mechanisms of action is insufficient. Among them, in the human pathogen $S$. aureus, two type I TA systems are located within a pathogenicity island $(\mathrm{PI})$ and express membrane toxic peptides whose overexpression causes bacterial cell death. PepA1, translated from the "sprA1/sprA1 As" locus, is induced upon acidic and oxidative stresses [46]. PepG1 $1_{31}$ and PepG1 $1_{44}$ are both translated from the "sprG1/sprF1" locus. Extracellular addition of either the three chemically-synthesized peptides or of membrane extracts prepared from $S$. aureus cells overexpressing PepG1 $1_{44}$ and $P e p G 1_{31}$ will trigger the lysis of both competing bacteria and human erythrocytes $[6 \bullet, 7]$. NMR structures and dynamic simulations indicate that synthetic PepA1 possesses an a-helical structure and can insert into the membrane. These toxic peptides probably damage bacterial membranes and erythrocytes through poreformation, membrane disruption due to a detergent-like effect, or by interference with membraneassociated functions, nevertheless we cannot exclude a role of these toxins in nucleoid condensation [46].

\section{2/Cytoplasmic type I toxins that cleave nucleic acids}

While a large number of membrane-associated type I toxins have been described, the only reported to be located in the cytoplasm have been SymE and RaIR. Contrary to the other type I toxins, SymE and RalR lack putative transmembrane segments and cleave nucleic acids.

\section{a- RNA cleavage}


SymE is a 113-amino acid peptide that, like the MazE type II antitoxin, contains an AbrB [47]. SymE and its homologs constitute a distinct family within the AbrB superfamily. Indeed, all of the other AbrB family members are transcription factors acting as antitoxins, while the SymE homologs have become toxic proteins. SymE toxin synthesis is downregulated additively at multiple levels: at the transcriptional level by LexA; at the mRNA stability level by the cis-encoded SymR antitoxin RNA and at the translational level by SymR and Lon proteases [12]. In E. coli, the SymE protein co-purifies with ribosomal proteins, and its overexpression drastically affects colonyforming ability and protein synthesis [12]. Overexpression of symE mRNA decreases levels of all tested mRNAs and regulatory RNAs except its antitoxin SymR. Moreover, after symE mRNA induction, distinct shorter mRNA fragments were observed. These results suggest that SymE acts as an endoribonuclease and cleaves mRNAs that should not be translated $[12,48]$. The DNA damaging agent mitomycin $\mathrm{C}$ induces overexpression of symE mRNA at both the mRNA and protein levels, suggesting a role for SymE toxin in simultaneously recycling damaged RNAs and DNAs during the SOS response.

\section{b- DNA cleavage}

The "ralR/ralA" locus is located on the E. coli rac prophage. ralR mRNA encodes a 64-amino acid type I toxin, and its overexpression leads to cell growth inhibition, while the RalA antitoxin requires the Hfq chaperone to stabilize it [13•]. In vitro DNA cleavage assays have shown that purified RalR toxin is a non-specific endonuclease that cleaves methylated or non-methylated DNAs. Furthermore, in vitro RNA cleavage assays do not reveal any RNA-targeting cleavage activity. Finally, overproduction of ralR mRNA causes a filamentous growth resulting from the SOS response following DNA degradation. The positive effects of the ralR/RalA TA system on cell physiology and fosfomycin resistance were confirmed through monitoring the growth and metabolic activity of wild-type and ralR/ralA knockout strains in the presence of fosfomycin, an inhibitor of bacterial cell wall biogenesis [13•]. 


\section{2- Concluding remarks and perspectives}

When examined together, the effects of some type I toxins on bacterial physiology challenge the concept that membrane-associated type I toxins act solely by pore formation. This is why we propose an updated nomenclature with two classes of type I toxins. These classes are based on peptide location and their mechanisms of action: (i) membrane-associated toxins act either by pore formation and/or nucleoid condensation; and (ii) cytoplasmic toxins that catalyze nucleic acid cleavages. Table 1 summarizes the type I toxins according to the current understanding of their mechanisms of actions, and underlines the two different classes. Our nomenclature only includes the modes of action that are currently well-described, and will thus evolve based on future discoveries, but it provides a solid basis for better understanding of the TA systems. In particular, it would be appropriate to investigate whether, like many other antibacterial peptides, certain type I toxic peptides could induce a membrane disruption via the "carpet" mechanism (where peptides bind to the surface of the membrane and provoke a detergent-like effect) [49]. Moreover, the effect of the pore-forming peptides on the nucleoid condensation is usually left unexplored, so it is tempting to speculate that some may act through both mechanisms. Another important challenge would be to determine whether there is heterogeneity in toxin expression within a cell population, along with an exploration of the various triggers and signaling pathways that induce toxin expression. New hypotheses about the biological functions of toxic peptides will arise from a better understanding of their mechanisms and the identification of their molecular targets. Finally, TA systems should be considered as tiny modules embedded in larger regulatory networks where all of the different players interact. Indeed, recent discoveries implying crosstalk between type I and II TAs [50] suggest that numerous interactions involving different TA systems are yet to be discovered.

The unique characteristics of TA loci make them of particular interest for biotechnological applications. TAs can be considered lead compounds for the design of new antimicrobials, plasmid maintenance tools, vaccines, and selective reporter genes [51,52]. Moreover, toxins on their own can also have various applications. Indeed, selective cloning vectors containing variants 
213 of IbsC, a type I E. coli toxic peptide, have been engineered [53]. In addition, chemical

214 modifications of PepA1 toxin dramatically increased its antibacterial potential and its stability in 215 human serum while considerably reducing its human cell toxicity, implying that toxins can be 216 transformed into potent antibiotics [27]. The DinQ toxin is another promising candidate for the 217 development of anti-cell-envelope antibiotics, notably against E. coli infection [54]. These 218 strategies could be applied to other toxic peptides, notably for the design of new antibiotics, thus 219 providing alternatives to the burgeoning issue of bacterial resistance to the drugs presently in use. 
Figure captions

Table 1: Overview of the type I TA classes based on the mechanisms of action of toxins.

\section{Figure 1: Reported functions for type I pore-forming toxins.}

Some type I toxins expressed in response to stresses (yellow lightning) or after plasmid loss (dark grey) are located within membranes (grey), where they form pores. These pores decrease the membrane potential, cell energy levels and proton motive force (PMF), eventually leading to cell growth arrest or cell lysis of a population fraction. Plasmid maintenance, persistence, and stress adaptation were among the biological functions identified for type I pore-forming toxins located in the membrane.

\section{Figure 2: Fst toxin: an example of a "domino effect” post-segregational killing (PSK).} Within E. faecalis, PSK bacterial maintenance of the pAD1 plasmid (dark grey) involves the par locus. After bacterial division, RNAI toxin mRNA and RNAll antitoxin are both expressed within the daughter cells carrying the plasmid (at left). They can form a stable RNA duplex that prevents toxin mRNA translation without effecting bacterial growth. Within the daughter cells lacking plasmids (at right), the unstable RNAll antitoxin is degraded and does not downregulate RNAI toxin translation. The toxic peptide is expressed, migrates, and accumulates at the membrane. After 15 minutes, this induces an aberrant nucleoid condensation, altered synthesis of peptidoglycan, abnormal cell division and septum placement, resulting in unequal DNA distribution among the daughter cells. After 60 minutes, probably in response to these initial triggers, Fst toxin induces transcription of numerous target genes including transporters, and results finally in cell death [23],[42]. 


\section{Acknowledgments}

The authors acknowledge financial support from Universities of Rennes 1 (France), Bern

(Switzerland), and Sherbrooke (Canada, grant 'Fonds de recherche Nature et Technologie de

Québec'), as well as from the French institutes, the 'Institut National de la Santé et de la

Recherche Médicale' (INSERM) the School of Pharmacy and Medical Sciences of Rennes 1

University, and the French Medical Research Foundation (FRM). We also thank P. Bouloc, Y.

Augagneur, G. Pascreau, and M. Sassi from our lab and J. Berland for proof reading the review.

\section{References}

1. Gerdes K, Rasmussen PB, Molin S: Unique type of plasmid maintenance function: postsegregational killing of plasmid-free cells. Proceedings of the National Academy of Sciences of the United States of America 1986, 83:3116-3120.

2. Brantl S, Jahn N: sRNAs in bacterial type I and type III toxin-antitoxin systems. FEMS microbiology reviews 2015, 39:413-427.

3. Goeders N, Van Melderen L: Toxin-antitoxin systems as multilevel interaction systems. Toxins 2014, 6:304-324.

4. Fozo EM, Makarova KS, Shabalina SA, Yutin N, Koonin EV, Storz G: Abundance of type I toxin-antitoxin systems in bacteria: searches for new candidates and discovery of novel families. Nucleic acids research 2010, 38:3743-3759.

5. Fozo EM, Kawano M, Fontaine F, Kaya Y, Mendieta KS, Jones KL, Ocampo A, Rudd KE, Storz G: Repression of small toxic protein synthesis by the Sib and OhsC small RNAs. Molecular microbiology 2008, 70:1076-1093.

6•. Pinel-Marie ML, Brielle R, Felden B: Dual toxic-peptide-coding Staphylococcus aureus RNA under antisense regulation targets host cells and bacterial rivals unequally. Cell reports 2014, 7:424-435.

This study have identified an unconventional type I toxin-antitoxin system expressed from a human pathogen. In this TAs, toxin expresses two hemolytic and antibacterial peptides from a dual-coding RNA, unless its dual-acting antisense RNA inhibits it.

7. Sayed N, Jousselin A, Felden B: A cis-antisense RNA acts in trans in Staphylococcus aureus to control translation of a human cytolytic peptide. Nature structural \& molecular biology 2012, 19:105-112.

8. Silvaggi JM, Perkins JB, Losick R: Small untranslated RNA antitoxin in Bacillus subtilis. Journal of bacteriology 2005, 187:6641-6650.

9. Darfeuille F, Unoson C, Vogel J, Wagner EG: An antisense RNA inhibits translation by competing with standby ribosomes. Molecular cell 2007, 26:381-392.

10. Jahn N, Brantl S: One antitoxin-two functions: SR4 controls toxin mRNA decay and translation. Nucleic acids research 2013, 41:9870-9880.

11. Wen J, Fozo EM: sRNA antitoxins: more than one way to repress a toxin. Toxins 2014, 6:2310-2335.

12. Kawano M, Aravind L, Storz G: An antisense RNA controls synthesis of an SOS-induced toxin evolved from an antitoxin. Molecular microbiology 2007, 64:738-754.

13•. Guo Y, Quiroga C, Chen Q, McAnulty MJ, Benedik MJ, Wood TK, Wang X: RalR (a DNase) and RalA (a small RNA) form a type I toxin-antitoxin system in Escherichia coli. Nucleic acids research 2014, 42:6448-6462.

This report describes a toxin-antitoxin system in which the toxin acts as a non-specific endodesoxiribonuclease.

14••. Jahn N, Brantl S, Strahl H: Against the mainstream: the membrane-associated type I toxin BsrG from Bacillus subtilis interferes with cell envelope biosynthesis without increasing membrane permeability. Molecular microbiology 2015.

Most type I toxins are small hydrophobic membrane peptides and are assumed to target cytoplasmic membrane and, as a result, to induce cell death. The srG/SR4 Toxin-antitoxin module does not dissipate 
membrane potential nor affects cellular ATP-levels but strongly interferes with the envelope biosynthesis, causing membrane invaginations and triggering autolysis.

15. Gerdes K, Bech FW, Jorgensen ST, Lobner-Olesen A, Rasmussen PB, Atlung T, Boe L, Karlstrom O, Molin S, von Meyenburg K: Mechanism of postsegregational killing by the hok gene product of the parB system of plasmid R1 and its homology with the relF gene product of the E. coli relB operon. The EMBO journal 1986, 5:2023-2029.

16••. Verstraeten N, Knapen WJ, Kint Cl, Liebens V, Van den Bergh B, Dewachter L, Michiels JE, Fu Q, David CC, Fierro AC, et al.: Obg and Membrane Depolarization Are Part of a Microbial Bet-Hedging Strategy that Leads to Antibiotic Tolerance. Molecular cell 2015, 59:9-21.

A universally conserved GTPase induces bacterial multidrug tolerance at single-cell level by transcriptional activation of a type I toxin. The peptide, encoded by a type I toxin-antitoxin module, provokes a collapse in the membrane potential, which ultimately results in bacterial persistence state. These findings are an important step toward unraveling shared genetic mechanisms underlying persistence.

17•. Chukwudi CU, Good L: The role of the hok/sok locus in bacterial response to stressful growth conditions. Microbial pathogenesis 2015, 79:70-79.

This study showed that the hok/sok locus prolonges the bacterial lag phase in unfavorable conditions to enabling the cells to adapt to the stress such as high temperature and antibiotic.

18. Vogel J, Argaman L, Wagner EG, Altuvia S: The small RNA IstR inhibits synthesis of an SOS-induced toxic peptide. Current biology : CB 2004, 14:2271-2276.

19. Dorr T, Vulic M, Lewis K: Ciprofloxacin causes persister formation by inducing the TisB toxin in Escherichia coli. PLoS biology 2010, 8:e1000317.

20. Gurnev PA, Ortenberg R, Dorr T, Lewis K, Bezrukov SM: Persister-promoting bacterial toxin TisB produces anionselective pores in planar lipid bilayers. FEBS letters 2012, 586:2529-2534.

21. Weel-Sneve R, Kristiansen KI, Odsbu I, Dalhus B, Booth J, Rognes T, Skarstad K, Bjoras M: Single transmembrane peptide DinQ modulates membrane-dependent activities. PLoS genetics 2013, 9:e1003260.

22. Weaver KE, Reddy SG, Brinkman CL, Patel S, Bayles KW, Endres JL: Identification and characterization of a family of toxin-antitoxin systems related to the Enterococcus faecalis plasmid pAD1 par addiction module. Microbiology 2009, 155:2930-2940.

23. Brinkman CL, Bumgarner R, Kittichotirat W, Dunman PM, Kuechenmeister LJ, Weaver KE: Characterization of the effects of an rpoC mutation that confers resistance to the Fst peptide toxin-antitoxin system toxin. Journal of bacteriology 2013, 195:156-166.

24. Rudd KE: Novel intergenic repeats of Escherichia coli K-12. Research in microbiology 1999, 150:653-664.

25. Kawano M, Oshima T, Kasai H, Mori H: Molecular characterization of long direct repeat (LDR) sequences expressing a stable mRNA encoding for a 35-amino-acid cell-killing peptide and a cis-encoded small antisense RNA in Escherichia coli. Molecular microbiology 2002, 45:333-349.

26. Jahn N, Preis H, Wiedemann C, Brantl S: bsrG/SR4 from Bacillus subtilis--the first temperature-dependent type I toxin-antitoxin system. Molecular microbiology 2012, 83:579-598.

27. Solecki O, Mosbah A, Baudy Floc'h M, Felden B: Converting a Staphylococcus aureus toxin into effective cyclic pseudopeptide antibiotics. Chemistry \& biology 2015, 22:329-335.

28. Akimoto S, Ohnishi Y: R483 and F plasmid genes promoting RNA degradation: comparative restriction mapping. Microbiology and immunology 1982, 26:779-793.

29. Ono K, Akimoto S, Ohnishi Y: Nucleotide sequence of the pnd gene in plasmid R483 and role of the pnd gene product in plasmolysis. Microbiology and immunology 1987, 31:1071-1083.

30. Nielsen AK, Thorsted $P$, Thisted T, Wagner EG, Gerdes K: The rifampicin-inducible genes srn $B$ from $F$ and pnd from R483 are regulated by antisense RNAs and mediate plasmid maintenance by killing of plasmid-free segregants. Molecular microbiology 1991, 5:1961-1973.

31. Thisted T, Nielsen AK, Gerdes K: Mechanism of post-segregational killing: translation of Hok, SrnB and Pnd mRNAs of plasmids R1, F and R483 is activated by 3'-end processing. The EMBO journal 1994, 13:19501959.

32. Fozo EM: New type I toxin-antitoxin families from "wild" and laboratory strains of E. coli: Ibs-Sib, ShoB-OhsC and Zor-Orz. RNA biology 2012, 9:1504-1512.

33. Kawano M, Reynolds AA, Miranda-Rios J, Storz G: Detection of 5'- and 3'-UTR-derived small RNAs and cisencoded antisense RNAs in Escherichia coli. Nucleic acids research 2005, 33:1040-1050.

34. Koyanagi S, Levesque CM: Characterization of a Streptococcus mutans intergenic region containing a small toxic peptide and its cis-encoded antisense small RNA antitoxin. PloS one 2013, 8:e54291.

35. Durand S, Jahn N, Condon C, Brantl S: Type I toxin-antitoxin systems in Bacillus subtilis. RNA biology 2012, 9:1491-1497. 
36. Nicolas P, Mader U, Dervyn E, Rochat T, Leduc A, Pigeonneau N, Bidnenko E, Marchadier E, Hoebeke M, Aymerich $S$, et al.: Condition-dependent transcriptome reveals high-level regulatory architecture in Bacillus subtilis. Science 2012, 335:1103-1106.

37. Poulsen LK, Larsen NW, Molin S, Andersson P: A family of genes encoding a cell-killing function may be conserved in all gram-negative bacteria. Molecular microbiology 1989, 3:1463-1472.

38. Pedersen K, Gerdes K: Multiple hok genes on the chromosome of Escherichia coli. Molecular microbiology 1999, 32:1090-1102.

39. Steinbrecher T, Prock S, Reichert J, Wadhwani P, Zimpfer B, Burck J, Berditsch M, Elstner M, Ulrich AS: Peptidelipid interactions of the stress-response peptide TisB that induces bacterial persistence. Biophysical journal 2012, 103:1460-1469.

40. Patel S, Weaver KE: Addiction toxin Fst has unique effects on chromosome segregation and cell division in Enterococcus faecalis and Bacillus subtilis. Journal of bacteriology 2006, 188:5374-5384.

41. Dintner S, Staron A, Berchtold E, Petri T, Mascher T, Gebhard S: Coevolution of ABC transporters and twocomponent regulatory systems as resistance modules against antimicrobial peptides in Firmicutes Bacteria. Journal of bacteriology 2011, 193:3851-3862.

42. Weaver KE: The par toxin-antitoxin system from Enterococcus faecalis plasmid pAD1 and its chromosomal homologs. RNA biology 2012, 9:1498-1503.

43••. Michaux C, Hartke A, Martini C, Reiss S, Albrecht D, Budin-Verneuil A, Sanguinetti M, Engelmann S, Hain T, Verneuil $\mathrm{N}$, et al.: Involvement of Enterococcus faecalis small RNAs in stress response and virulence. Infection and immunity 2014, 82:3599-3611.

This report that highlight the functions of certain candidate sRNAs in the adaptation of $E$. faecalis to environmental changes has shown that a mutant lacking an homolog of a toxin-antitoxin locus is hypervirulent and has increased abilities to colonize mice.

44. Yamaguchi Y, Tokunaga N, Inouye M, Phadtare S: Characterization of LdrA (long direct repeat A) protein of Escherichia coli. Journal of molecular microbiology and biotechnology 2014, 24:91-97.

45. Fernandez De Henestrosa AR, Ogi T, Aoyagi S, Chafin D, Hayes JJ, Ohmori H, Woodgate R: Identification of additional genes belonging to the LexA regulon in Escherichia coli. Molecular microbiology 2000, 35:15601572.

46. Sayed N, Nonin-Lecomte S, Rety S, Felden B: Functional and structural insights of a Staphylococcus aureus apoptotic-like membrane peptide from a toxin-antitoxin module. The Journal of biological chemistry 2012, 287:43454-43463.

47. Coles M1, Djuranovic S, Söding J, Frickey T, Koretke K, Truffault V, Martin J, Lupas AN: AbrB-like transcriptionfactors assume a swapped hairpin fold that is evolutionarily related to double-psi beta barrels. Structure 2005 Jun;13(6):919-28

48. Kawano M: Divergently overlapping cis-encoded antisense RNA regulating toxin-antitoxin systems from $E$. coli: hok/sok, Idr/rdl, symE/symR. RNA biology 2012, 9:1520-1527.

49. Dufourc EJ, Buchoux S, Toupe J, Sani MA, Jean-Francois F, Khemtemourian L, Grelard A, Loudet-Courreges C, Laguerre M, Elezgaray J, et al.: Membrane interacting peptides: from killers to helpers. Current protein \& peptide science 2012, 13:620-631.

50. Wessner F, Lacoux C, Goeders N, d'Herouel AF, Matos R, Serror P, Van Melderen L, Repoila F: Regulatory crosstalk between type I and type II toxin-antitoxin systems in the human pathogen Enterococcus faecalis. RNA biology 2015:0.

51. Ghafourian S, Raftari M, Sadeghifard N, Sekawi Z: Toxin-antitoxin Systems: Classification, Biological Function and Application in Biotechnology. Current issues in molecular biology 2014, 16:9-14.

52. Demidenok OI, Goncharenko AV: [Bacterial toxin-antitoxin systems and perspectives for their application in medicine: a review]. Prikladnaia biokhimiia i mikrobiologiia 2013, 49:539-546.

53. Mok WW, Li Y: A highly efficient molecular cloning platform that utilises a small bacterial toxin gene. Chembiochem : a European journal of chemical biology 2013, 14:733-738.

54. Booth JA, Suganthan R, Gaustad P, Bjoras M: Development of DinQ from Escherichia coli as an anti-cellenvelope antibiotic. International journal of antimicrobial agents 2015, 45:196-197. 


\begin{tabular}{|c|c|c|c|c|c|c|}
\hline Class & $\begin{array}{l}\text { Type I toxin } \\
\text { mechanisms } \\
\text { of action }\end{array}$ & $\begin{array}{l}\text { Mechanisms } \\
\text { of action } \\
\text { discovered } \\
\text { through: }\end{array}$ & TA systems & Locations & $\begin{array}{l}\text { Biological functions } \\
\text { (discovered through:) }\end{array}$ & Refs \\
\hline \multirow{15}{*}{ 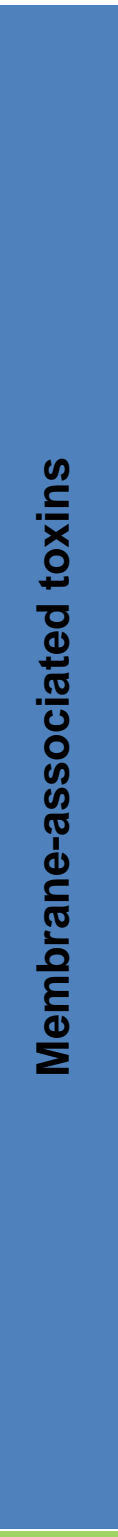 } & \multirow[t]{2}{*}{ Pore formation } & Overexpression $^{3}$ & hok/Sok ${ }^{1}$ & $\begin{array}{l}\text { - E. coli } \\
\text { R1 plasmid } \\
\text { - Numerous } \\
\text { Gram- genomes }\end{array}$ & $\begin{array}{l}\text { - Plasmid maintenance (ectopic } \\
\text { expression }^{2} \text { ) } \\
\text { - Obg-mediated persistence (deletion) } \\
\text { - Stress response to temperatures, } \\
\text { antibiotics, SOS, etc. (ectopic } \\
\text { expression }{ }^{2} \text { ) }\end{array}$ & $\begin{array}{l}{[15]} \\
{[16 \bullet \bullet]} \\
{[17 \bullet]}\end{array}$ \\
\hline & & $\begin{array}{l}\text { Chemically } \\
\text { synthesized }\end{array}$ & tisB/IstR $1^{1}$ & $\begin{array}{l}\text { - E. coli } \\
\text { chromosome }\end{array}$ & $\begin{array}{l}\text { - SOS-mediated persistence by inducing } \\
\text { DNA repair and dormancy (deletion) }\end{array}$ & {$[18-20]$} \\
\hline & \multirow{4}{*}{$\begin{array}{l}\text { Nucleoid } \\
\text { condensation }\end{array}$} & Overexpression $^{3}$ & $\operatorname{din} Q / A g r B$ & $\begin{array}{l}\text { - E. coli } \\
\text { chromosome }\end{array}$ & $\begin{array}{l}\text { - SOS response (overexpression }{ }^{3} \text { ) } \\
\text { - Conjugal recombination (deletion) }\end{array}$ & [21] \\
\hline & & Overexpression $^{3}$ & RNAI/RNAII ${ }^{1}$ & $\begin{array}{l}\text { - E. faecalis } \\
\text { pAD1 plasmid }\end{array}$ & $\begin{array}{l}\text { - Plasmid maintenance (ectopic } \\
\text { expression }{ }^{2} \text { ) }\end{array}$ & {$[22,23]$} \\
\hline & & Overexpression $^{3}$ & $\operatorname{ldrD/RdID}{ }^{1}$ & $\begin{array}{l}\text { - E. coli } \\
\text { chromosome }\end{array}$ & $\begin{array}{l}\text { - Involved in purin metabolism and cAMP } \\
\text { levels (overexpression }{ }^{3} \text { ) }\end{array}$ & $\begin{array}{l}{[24]} \\
{[25]}\end{array}$ \\
\hline & & Overexpression $^{3}$ & bsrG/SR4 ${ }^{1}$ & $\begin{array}{l}\text { - B. subtilis } \\
\text { SP } \beta \text { prophage }\end{array}$ & - Unknown & $\begin{array}{l}{[14 \bullet \bullet]} \\
{[26]}\end{array}$ \\
\hline & \multirow{9}{*}{$\begin{array}{l}\text { To be } \\
\text { confirmed }\end{array}$} & $\begin{array}{l}\text { Chemically } \\
\text { synthesized }^{4}\end{array}$ & sprA1/SprA1 ${ }_{1}$ AS & $\begin{array}{l}-S \text {. aureus } \\
\mathrm{v} \sum \alpha \beta \\
\text { pathogenicity } \\
\text { island }\end{array}$ & $\begin{array}{l}\text { - Acidic and oxidative stress responses } \\
\text { (overexpression }^{3} \text { ) } \\
\text { - Competing bacterial and human } \\
\text { erythrocyte lysis (chemical synthesis }{ }^{4} \text { ) }\end{array}$ & $\begin{array}{l}{[7]} \\
{[27]}\end{array}$ \\
\hline & & $\begin{array}{l}\text { Chemically } \\
\text { synthesized }\end{array}$ & sprG1/SprF1 ${ }^{1}$ & $\begin{array}{l}\text { - S. aureus } \\
\text { SaPIn3 } \\
\text { pathogenicity } \\
\text { island }\end{array}$ & $\begin{array}{l}\text { - Competing bacterial and human } \\
\text { erythrocyte lysis (chemical synthesis }{ }^{4} \text { and } \\
\text { membrane extraction) }\end{array}$ & {$[6 \cdot]$} \\
\hline & & & pnd & $\begin{array}{l}\text { - E. coli } \\
\text { R483 plasmid }\end{array}$ & $\begin{array}{l}\text { - Plasmid maintenance (ectopic } \\
\text { expression }^{2} \text { ) }\end{array}$ & $\begin{array}{l}{[28]} \\
{[29,30]}\end{array}$ \\
\hline & & & $\operatorname{srn} B$ & $\begin{array}{l}-E . \text { coli } \\
\text { F plasmid }\end{array}$ & $\begin{array}{l}\text { - Plasmid maintenance (ectopic } \\
\text { expression }^{2} \text { ) }\end{array}$ & $\begin{array}{l}{[31]} \\
{[30]}\end{array}$ \\
\hline & & & $i b s C / S_{i b C}{ }^{1}$ & $\begin{array}{l}\text { - E. coli } \\
\text { chromosome }\end{array}$ & - Unknown & [32] \\
\hline & & & shoB/OhsC & $\begin{array}{l}\text { - E. coli } \\
\text { chromosome }\end{array}$ & $\begin{array}{l}\text { - Heat and oxidative stress response } \\
\left(\text { overexpression }^{3} \text { ) }\right. \\
\text { - Induction of carbohydrate transport } \\
\text { expression (overexpression }{ }^{3} \text { ) }\end{array}$ & $\begin{array}{l}{[33]} \\
{[32]}\end{array}$ \\
\hline & & & zorO/OrzO' & $\begin{array}{l}\text { - E. coli } \\
\text { chromosome }\end{array}$ & - Unknown & $\begin{array}{l}{[4]} \\
{[32]}\end{array}$ \\
\hline & & & $f s t-S m / S_{S S m}{ }^{1}$ & $\begin{array}{l}\text { - S. mutans } \\
\text { chromosome }\end{array}$ & $\begin{array}{l}\text { - Inhibits persistence (mild-over } \\
\text { expression }^{2} \text { ) }\end{array}$ & [34] \\
\hline & & & $\operatorname{txp} A / \operatorname{Rat}^{1}$ & $\begin{array}{l}\text { - B. subtilis } \\
\text { skin phage-like } \\
\text { element }\end{array}$ & - Cell metabolic state? (endogenous ${ }^{5}$ ) & $\begin{array}{l}{[8]} \\
{[35]} \\
{[36]}\end{array}$ \\
\hline \multirow{2}{*}{ 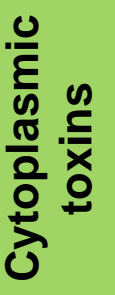 } & RNA cleavage & Overexpression $^{3}$ & symE/SymR ${ }^{1}$ & $\begin{array}{l}\text { - E. coli } \\
\text { chromosome }\end{array}$ & $\begin{array}{l}\text { - SOS response (endogenous }{ }^{5} \text { ) } \\
\text { - Recycling damaged RNAs } \\
\text { (overexpression }^{3} \text { ) }\end{array}$ & [12] \\
\hline & DNA cleavage & $\begin{array}{l}\text { Chemically } \\
\text { synthesized }^{4}\end{array}$ & $\mathrm{ralR} / \mathrm{RalA}$ & $\begin{array}{l}\text { - E. coli } \\
\text { rac prophage }\end{array}$ & - Fosfomycin resistance (deletion) & {$[13 \bullet]$} \\
\hline
\end{tabular}

${ }^{1}$ TA systems expressed in other bacteria and/or in other copies located in the bacterial genome.

${ }^{2}$ Plasmid maintenance identified using plasmid other than the plasmid of origin expressing the TA locus.

${ }^{3}$ Biological functions identified when the TA systems are highly expressed using overexpression plasmids with endogenous or inducible promoters.

${ }^{4}$ In vitro analysis with chemically synthesized peptides.

${ }^{5}$ The environmental conditions induce a modulation of the toxin mRNA expression in the wild-type strain. 


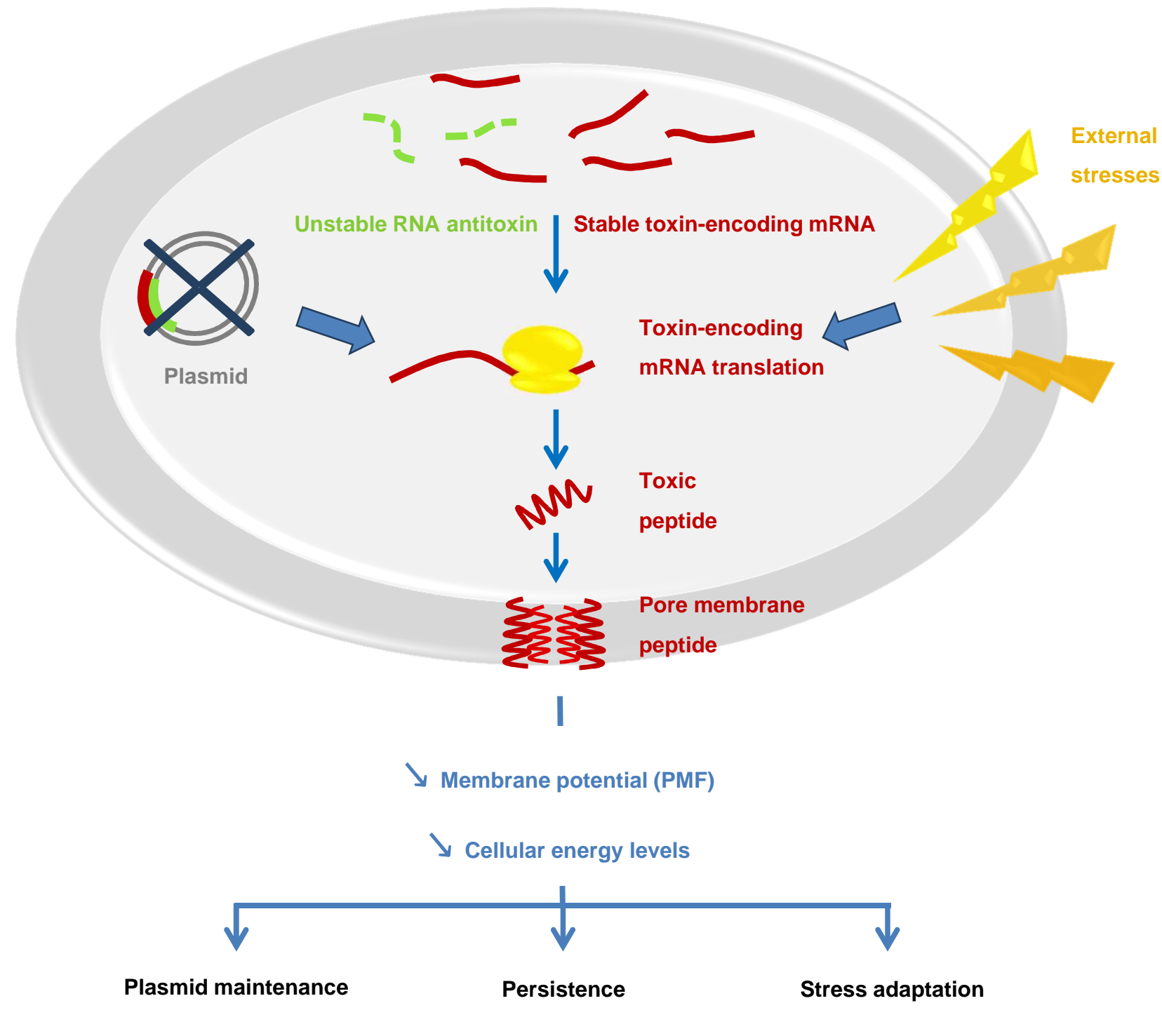




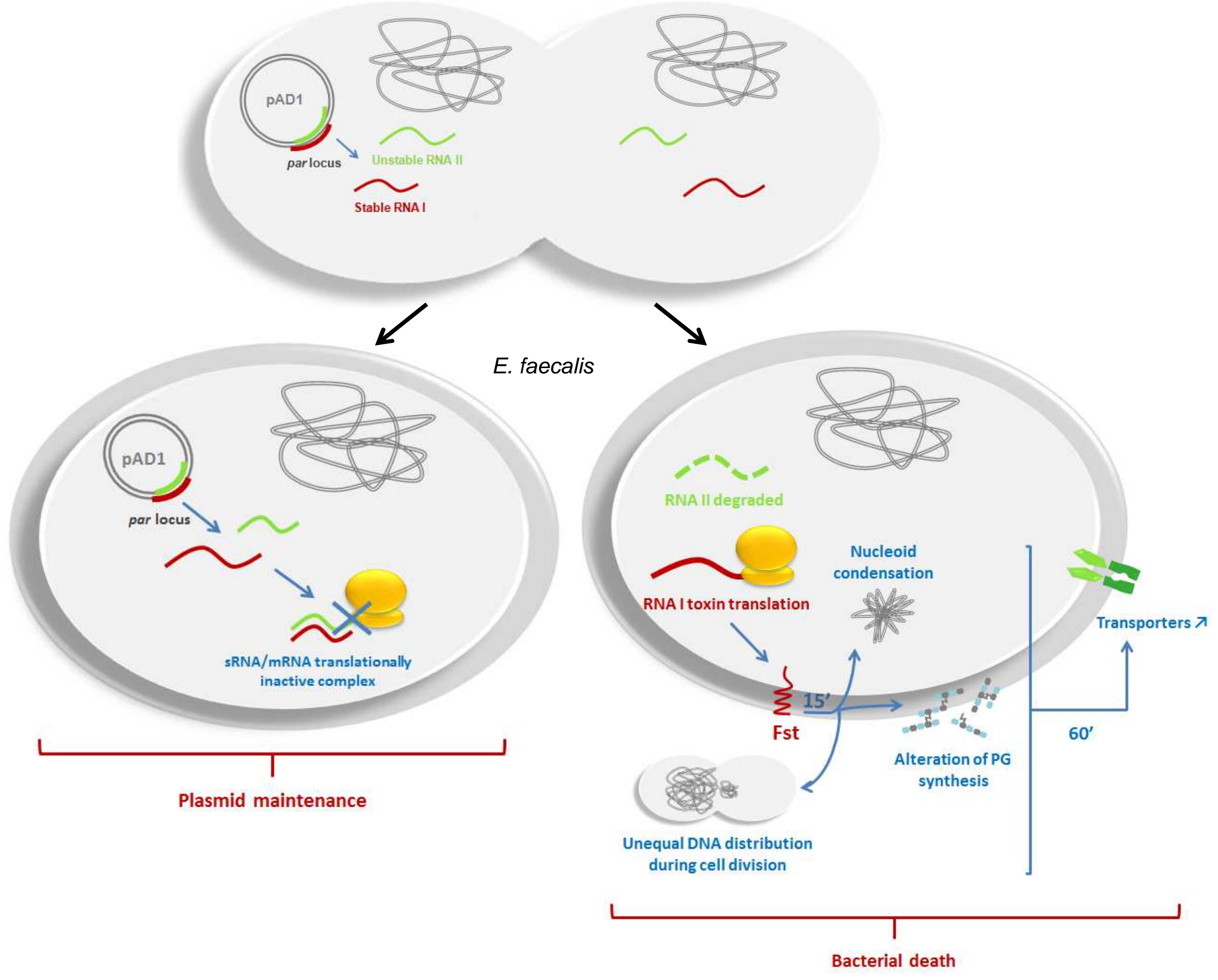




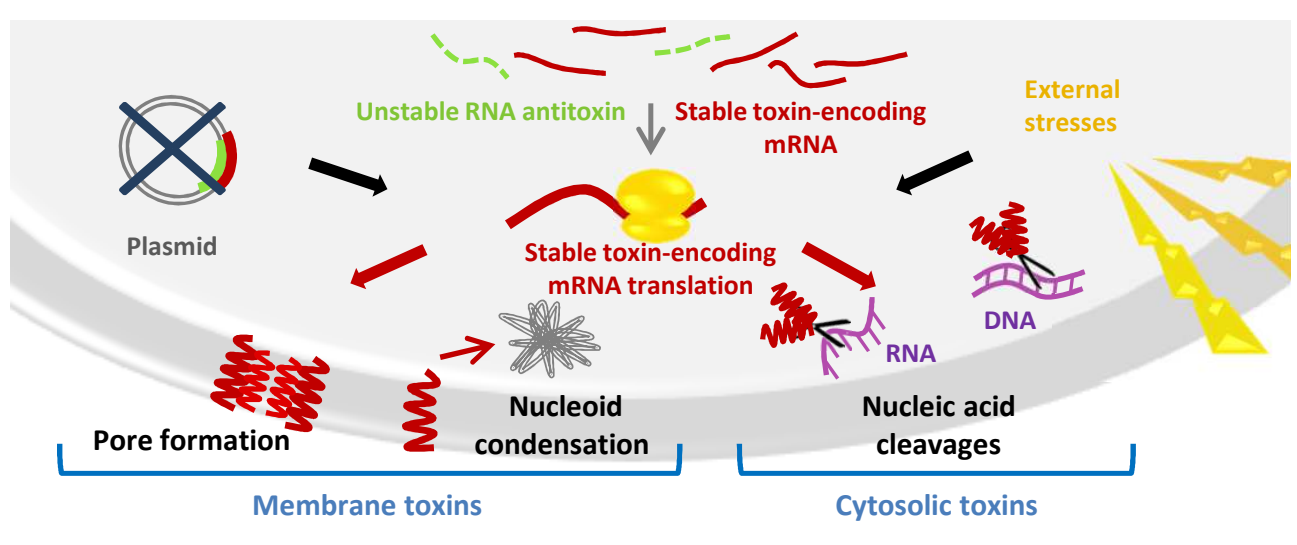

